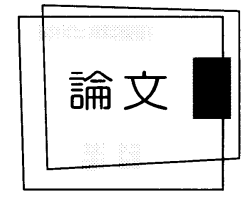

\title{
海水電解法を用いた舶用機関のCOx 後処理システムの開発*
}

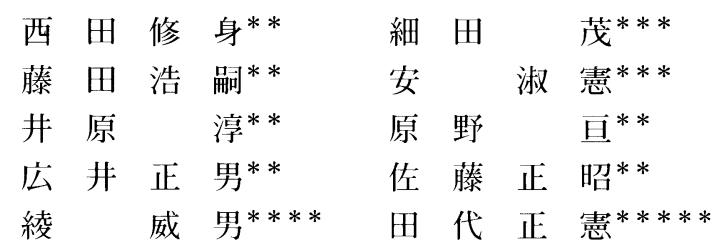

Development of After Treatment System on COx with Seawater Electrolysis for Marine Diesel Engine

By O. Nishida, S. Hosoda, S. An, A. Ihara,

H. Fujita, W. Harano M. Hiroi M. Sato T. Aya and M. Tashiro

Key Words：海水電解法, $\mathrm{CO}_{2}, \mathrm{COP} 3, \mathrm{IMO}$, アルカリ水, 隔膜

On the GHGs (Green-House Gases) exhausted from marine diesel engine, there are on overwhelming majority on marine $\mathrm{CO}_{2}$ (11,6134ton-Carbon). However, the drastic system to reduce $\mathrm{CO}_{2}$ has not been fundamentally settled ever today. This research makes a new technology to use the electrolyzed seawater for an after-treatment of marine $\mathrm{CO}_{2}$. This method produces a large amounts of an alkaline solution $(\mathrm{pH} \fallingdotseq 10)$ in the cathode room of electrolytic bath $(5 \mathrm{~A}, 10 \mathrm{~V})$, and there are the soluble reaction by the bubbled $\mathrm{CO}_{2}$ gas. The maximum removal rate of $\mathrm{CO}_{2}$ is about $80 \%$ from the experimental results.

\section{1. まえがき}

1997年地球温暖化防止京都会議 (COP3) におい て $\mathrm{CO}_{2}$ の排出量を規制するための京都議定書が採 択された。 とくに $\mathrm{CO}_{2}$ の排出が経済問題とも絡み 合い複雑である。船舶からの排出温室効果ガスの ほとんどが $\mathrm{CO}_{2}$ であり，11，6134t-Cといわれて おり，60\%以上がC重油使用による外航船舶によ るものである ${ }^{1)}$. わが国の船舶からの排出削減戦略 はIMOのMEPC (海洋環境保護委員会)での議論を ふまえ, IMOレポートを詳細に検討することを明 言している. $\mathrm{CO}_{2}$ の海洋での処理法としては溶解

\footnotetext{
*原稿受付 平成 14 年 6 月 14 日

**正 会 員 神戸商船大学 (神戸市東灘区深江南町 5-1-1)

$* * *$ 学 生 神戸商船大学 (神戸市東灘区深江南町 5-1-1)

$* * * *$ 海技研

資AST
}

法並びに貯留法が考えられている ${ }^{2)}$ が，技術的容易 性とコスト面から困難な問題があると考えられる。

本研究では航行船舶並びに沿岸域の火力発電所 から排出される $\mathrm{CO}_{2}$ を後処理法によって大幅に削 減する手法を提案するものである。海水を電気分 解し, 陰極室で得られたアルカリ水 $(\mathrm{pH} \fallingdotseq 10)$ 中の イオンと $\mathrm{CO}_{2}$ を反応させ，排出量を大幅削減する 策である。この種の研究はほとんどなされていな いため, 運輸施設整備事業団の御支援をいただき， 液中の $\mathrm{CO}_{2}$ 濃度を測定し，基礎的実験を行い検討 したので報告する。

\section{2. 電解法によるアルカリ生成と $\mathrm{CO}_{2}$ 溶解原理}

電気分解 (透析) 槽の基本構成を図 1 に示す。陰 陽極は液の流れを活性化するためメッシュ状とし た。両極室間に隔膜を設置し, 排ガスは容器下部 


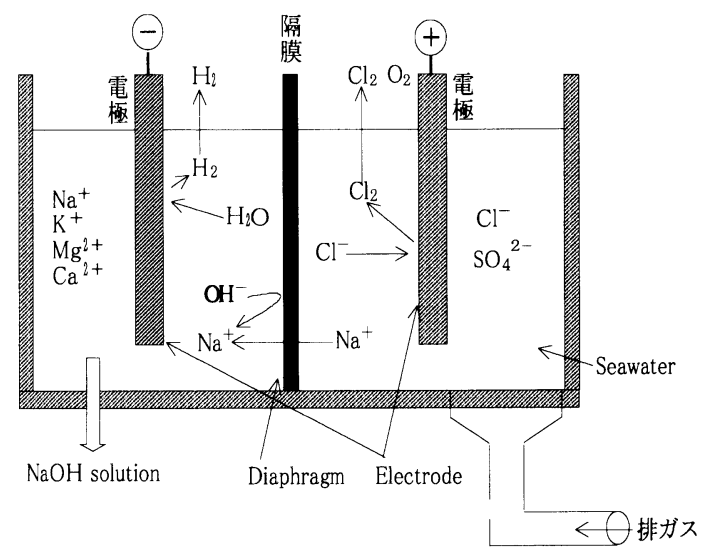

図1 電気分解槽基本構成図

から供給する。電極はチタンラスに白金メッキを 施したものである. 各極室の出入口には，バルブ が取り付けられており，通水量を調節することが できる。透析膜はイオン交換能, 強度, 効率等を 検討した結果，微細な多孔質の穴のテフロン製 (合 成樹脂)を採用した。隔膜の役割は，イオン伝導は 行うが，陰極室と陽極室の電解液を混合させない ことである．即ち，陰極でできたアルカリ $\left(\mathrm{OH}^{-}\right)$ と陽極でできた酸 $\left(\mathrm{H}^{+}\right)$を混合させないで，そのま ま保つことである。 また一般的に海水中の化合物 は $\mathrm{NaCl}$ が $69 \%$ を占め, $\mathrm{MgCl}_{2}, \mathrm{Na}_{2} \mathrm{SO}_{4}, \mathrm{CaCl}_{2}$, $\mathrm{KCl}$ 等が含まれている。陽イオンでは重量\%でナト リウムイオンが $30 \%$ 占めており，マグネシウムイ オン, カルシウムイオン等が存在する. 陰イオン では塩素イオンが $55 \%$ 占めて, 次いで硫酸イオン が存在する。よって海水の電気分解により, 㓌極 室のアルカリ水中には $\mathrm{NaOH}$, カルシウムイオン が生成・含有され, これらが以下のような反応を 経て炭酸ガスをアルカリ水中に溶解させる.

$\mathrm{CO}_{2}$ (陰極室：アルカリ水)

$2 \mathrm{H}_{2} \mathrm{O}+2 \mathrm{e}^{-} \rightarrow \mathrm{H}_{2}+2 \mathrm{OH}^{-}$

$\mathrm{CO}_{2}+2 \mathrm{OH}^{-} \rightarrow \mathrm{H}_{2} \mathrm{CO}_{3}+1 / 2 \mathrm{O}_{2}$

$\mathrm{H}_{2} \mathrm{CO}_{3}+\mathrm{NaOH} \rightarrow \mathrm{NaHCO}_{3}+\mathrm{H}_{2} \mathrm{O}(\mathrm{pH} \fallingdotseq 7 \sim 8) \cdots(3)$

$\mathrm{NaHCO}_{3}+\mathrm{NaOH} \rightarrow \mathrm{Na}_{2} \mathrm{CO}_{3}+\mathrm{H}_{2} \mathrm{O}(\mathrm{pH} \fallingdotseq 10 \sim 13) \cdots(4)$

$\mathrm{CO}_{3}{ }^{2-}+\mathrm{Ca}^{2+} \rightarrow \mathrm{CaCO}_{3}$

\section{3. 電気分解器 (槽) および測定法}

基礎的データをとるために, 罒 2 に示すような卓 上型電気分解槽を作成した，材料は透明塩化ビニー ル板製 (厚さ $10.5 \mathrm{~mm}$ )で，内容積 1.5 リットル 2 室 から出来て打り，電極には白金メッキをしたチタ ン材で, 電解槽内の溶液の流れを考慮しメッシュ 状のものを設置した.

\section{主要仕様 \\ (1)透明塩ビ製 $(10 t, 5 t)$ \\ (2) 内容 $1.5 \mathrm{~L} \times 2$ 室 \\ (3)ラス電極 $(75 \mathrm{~cm})$ \\ (白金素メッキ, Ti材) \\ (4) 隔膜 (330×150 テフロン) \\ (5)パッキング(ゴム $2 \mathrm{t}$ )}

\author{
6)ノズル及びバルブ各10A塩ビ付

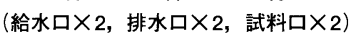 \\ (7)センサーロ $\times 2$, 予備ロ $\times 2$, 給気ロ $\times 1$ \\ (8)排気口 $20 A \times 1$, 電極端子 $\times 2$ \\ (9)使用電圧60V以下, 電流5A以下 \\ (10)吸気発生器 (5L/min, max) 1 個付
}

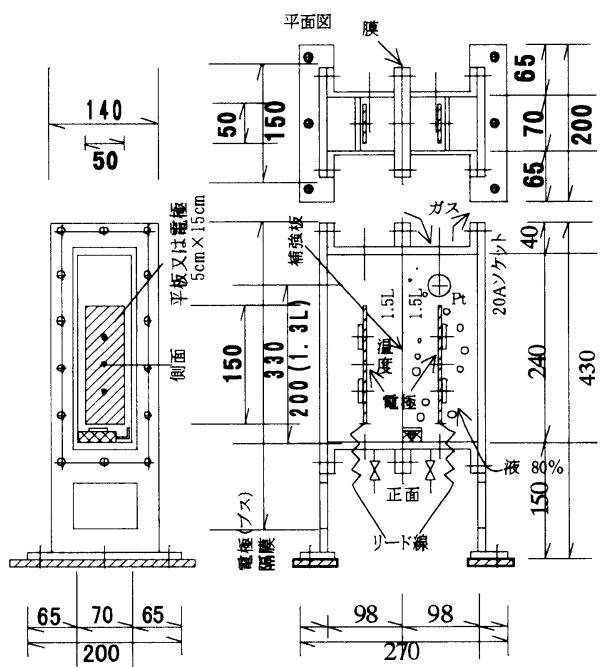

図2 卓上型電気分解槽
中間にテフロン製の隔膜 $(330 \times 150 \mathrm{~mm})$ を装着 した。

水質測定には燃焼触媒酸化法 (NDIR)による島 津製作所 $(\mathrm{K}, \mathrm{K})$ 製の全有機体炭素計 (TOC-VCSH) を使用した。ガス分析には $(\mathrm{K}, \mathrm{K})$ 堀場製作所製ポー タブルガス分析装置 (PG-200シリーズ)によった。

\section{4. 実験結果および考察}

4.1 アルカリ性と電流効率 電解槽の性能評 価のために電解電流 $(5 \mathrm{~A})$, 溶液 $(3.5 \% \mathrm{NaCl}$ と海 水) 並びに隔膜（孔径 $1 \mu \mathrm{m} ， 0.5 \mu \mathrm{m}$ ) を種々変えて, 電解時間に対して測定を行った. 
困3 (a) (b) は隔膜の厚さ $120 \mu \mathrm{m}$ で $5 \mathrm{~A}$ 定電流のも とで， $3.5 \% \mathrm{NaCl}$ 溶液と海水の場合について, $\mathrm{NaOH}$ 生成電流効率 $(\%)$ と $\mathrm{pH}$ 值を電解時間 $(\mathrm{min})$ に対して示した。 $\mathrm{NaOH}$ 生成電流効率とは，ある 值の電流值を流して理論的に生成される $\mathrm{NaOH} の$ 量に対して，実際に生成された $\mathrm{NaOH}$ の量の比率 を表したものである。（a）図の $\mathrm{NaCl}$ 溶液では $\mathrm{pH}$ 值 は電解時間 10 分以降において 12 を越えており， (b) 図の海水に比べ高いが, 電流効率は時間とと もに減少する。海水では $\mathrm{NaCl}$ 溶液より高い電流効 率(約 $100 \%)$ が得られたが, $\mathrm{Mg}(\mathrm{OH})_{2}$ 生成の沈殿 のために, $\mathrm{pH}$ 值は10止まりであった。

〔隔膜〕PTEF 孔径 : $1 \mu \mathrm{m}$, 多孔度 : $80 \%$, 厚さ : $120 \mu \mathrm{m}$

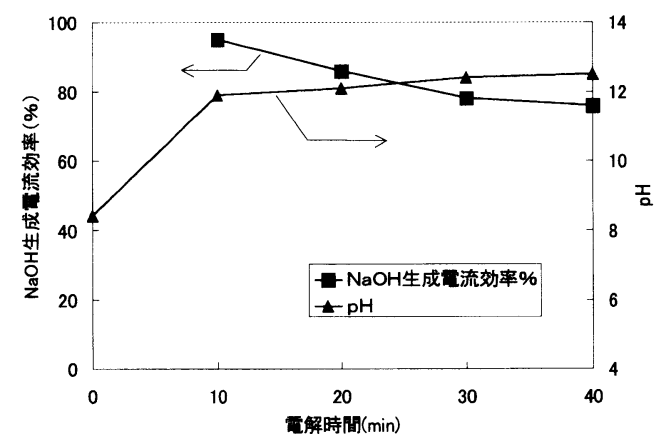

図3（a） 5 A 定電流 $3.5 \% \mathrm{NaCl}$ 溶液電解おける 電流効率と $\mathrm{pH}$ 変化

〔隔膜〕PTEF 孔径 : $1 \mu \mathrm{m}$, 多孔度 : $80 \%$, 厚さ : $120 \mu \mathrm{m}$

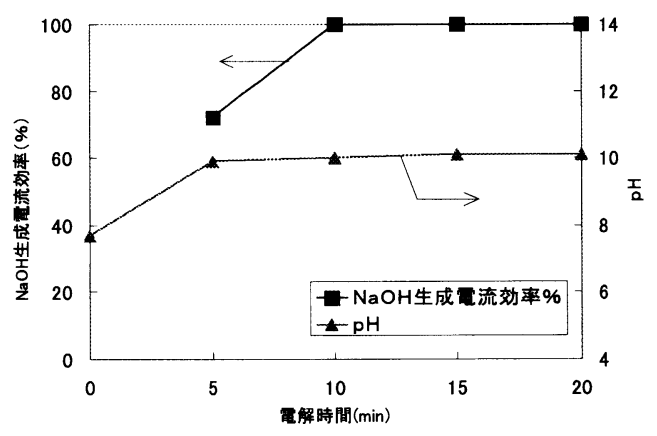

図3（b） 5A定電流海水溶液電解における 電流効率と $\mathrm{pH}$ 変化

図4 (a) (b) には同様に隔膜厚さ $35 \mu \mathrm{m}$ とした場合 の結果である。両液とも $\mathrm{pH}$ 值は厚さ $120 \mu \mathrm{m}$ の時と 変わらなかったが, (b) 図の海水の場合, $\mathrm{NaOH}$ 生
〔隔膜〕PTEF 孔径 : $0.5 \mu \mathrm{m}$, 多孔度 : $79 \%$, 厚さ : $35 \mu \mathrm{m}$

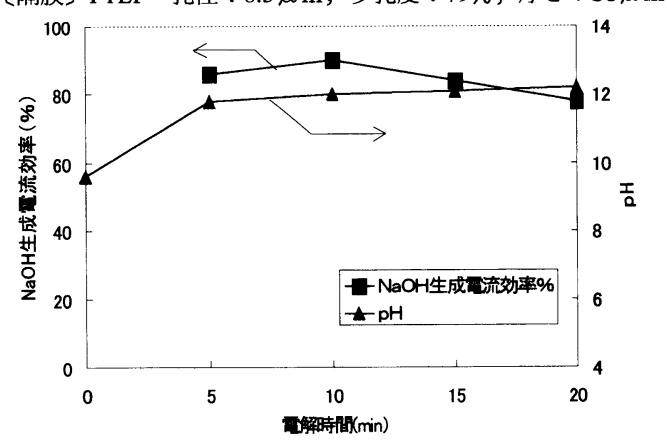

図4（a） 5A定電流3.5\% NaCl溶液電解における 電流効率と $\mathrm{pH}$ 変化

〔隔膜〕PTEF 孔径 : $0.5 \mu \mathrm{m}$, 多孔度 : $79 \%$, 厚さ : $35 \mu \mathrm{m}$

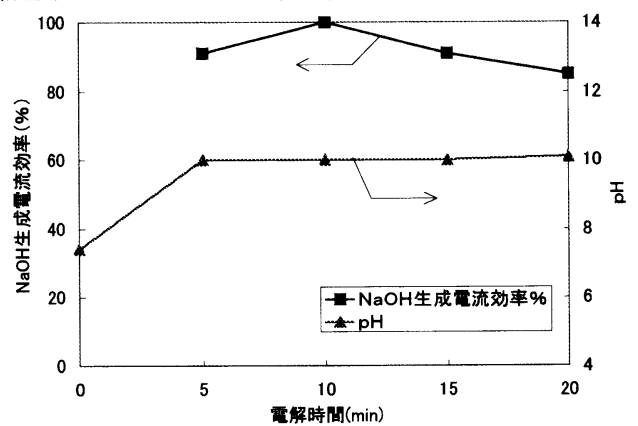

図4(b) 5A 定電流海水電解における 電流効率と $\mathrm{pH}$ 変化

成電流効率が厚さ $120 \mu \mathrm{m}$ に比べ約 $90 \%$ と若干下が るが，透析膜が有効であることがわかった．

罒5には電解電流の違いによる $\mathrm{NaOH}$ 生成電流効 率を表した。 5A電解の場合と比べ10A電解の場合 は少し効率が低下するが, 大差がなかった。

参考までに，陰極 (アノード) 側 $\mathrm{HCl}$ 生成電流効 率をプロットしたのが図6である，塩素ガスとして 大気へ放出されるため, 溶液中には少なくなるた め, 約十数\%であった。図7には隔膜の孔径 $(\phi 1 \mu \mathrm{m}, \phi 0.5 \mu \mathrm{m})$ の影響による電流効率を海水に より調べたが, 大きな差が認められなかった。

4.2 炭酸ガス溶解量 海水および $3.5 \% \mathrm{NaCl}$ 溶液の未電解 (処理) 水での炭酸ガスの溶解状態を 示したのが, 図8 (a), (b)である。溶液中の炭酸 ガス濃度 $\left(\mathrm{CO}_{2}-\mathrm{g} / \mathrm{L}\right)$ 変化及び $\mathrm{pH}$ 值を $\mathrm{CO}_{2}$ ガスの 
〔隔膜〕PTEF 孔径 : $1 \mu \mathrm{m}$, 多孔度 : $80 \%$, 厚さ : $120 \mu \mathrm{m}$

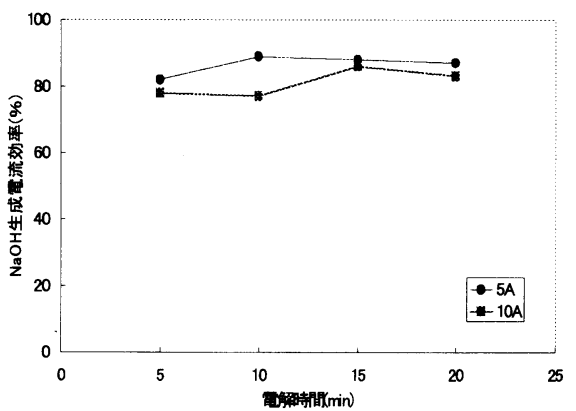

図5 3.5\% NaCl溶液電解における電流の影響

〔隔膜〕PTEF 孔径 : $1 \mu \mathrm{m}$, 多孔度 : $80 \%$, 厚さ : $120 \mu \mathrm{m}$

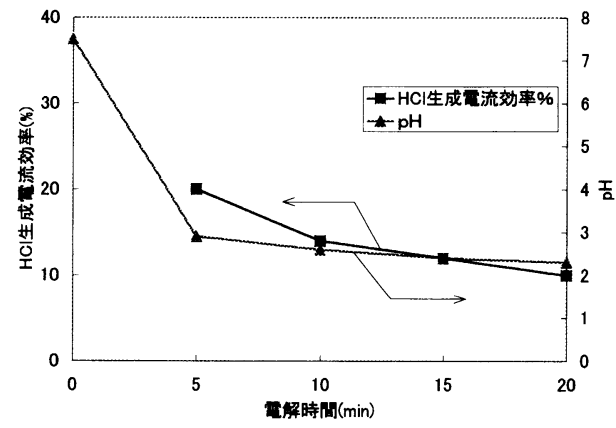

図6 5A定電流海水電解における 電流効率と $\mathrm{pH}$ の変化(アノード液)

〔隔膜〕PTEF 孔径 : $1 \mu \mathrm{m}$, 多孔度 : $80 \%$, 厚さ : $120 \mu \mathrm{m}$ 〔隔膜〕PTEF 孔径 : $0.5 \mu \mathrm{m}$, 多孔度 : $79 \%$, 厚さ : $35 \mu \mathrm{m}$

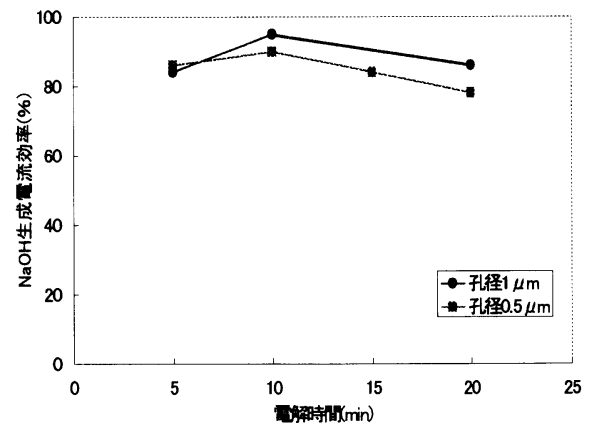

図7海水の $\mathrm{NaOH}$ 生成電流効率に及ぼす 孔径の影響
〔通気ガス〕 $5 \%$ 炭酸ガス, 流量 : $11 / \mathrm{min}$

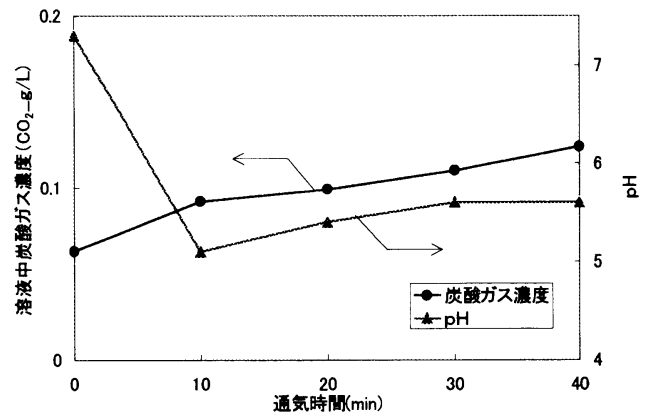

図8（a） 3.5\% NaCl溶液の炭酸ガス溶解量と $\mathrm{pH}$ 変化

〔通気ガス〕 $5 \%$ 炭酸ガス, 流量 : $11 / \mathrm{min}$

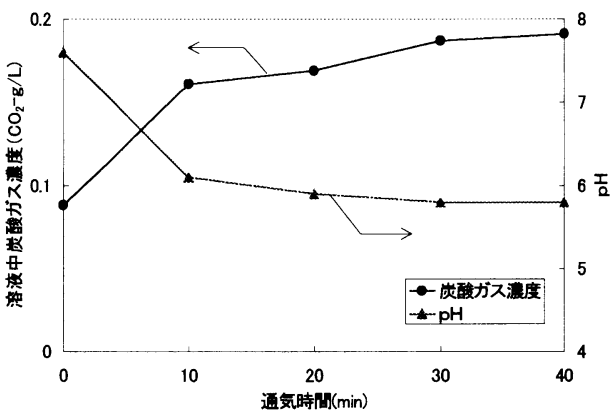

図8（b） 海水の炭酸ガス溶解量と $\mathrm{pH}$ 変化

通気時間に対して示した，炭酸ガスは濃度 $5 \%$ で流 速 $1 \mathrm{~L} / \mathrm{min}$ とした。ここで炭酸ガス溶解量とは溶液 中の炭酸ガス濃度の増加量をいう. $3.5 \% \mathrm{NaCl}$ 溶 液の炭酸ガスの溶解量は通気時間 40 分で約 $0.05 \mathrm{~g} / \mathrm{L}$ で，pHは通気時間が10分の所で最小值を示し，そ の後わずかに上昇した。これは炭酸ガス溶解に伴 い生成された $\mathrm{HCO}_{3}-$ - $\mathrm{pH}$ 緩衝能によるものと考え られる。海水の炭酸ガス溶解量は通気時間 40 分で 約 $0.1 \mathrm{~g} / \mathrm{L} て ゙, \mathrm{pH} 5.7$ 程度に低下した。これは海 水使用では重曹として溶け込み易いため, 高い值 を示した。

図9は5A通電 (一定) での両溶液 (海水及び $3.5 \%$ $\mathrm{NaCl})$ でのカソード液への $\mathrm{CO}_{2}$ 溶解量を電解時間 に対して示した。電解時間 0 は未処理水である. 電解時間が長くなるほど高アルカリ水になる．海 
〔隔膜〕PTEF 孔径 : $1 \mu \mathrm{m}$, 多孔度 : $80 \%$, 厚さ : $120 \mu \mathrm{m}$ 〔通気ガス〕 $5 \%$ 炭酸ガス, 流量 : $11 / \mathrm{min}$

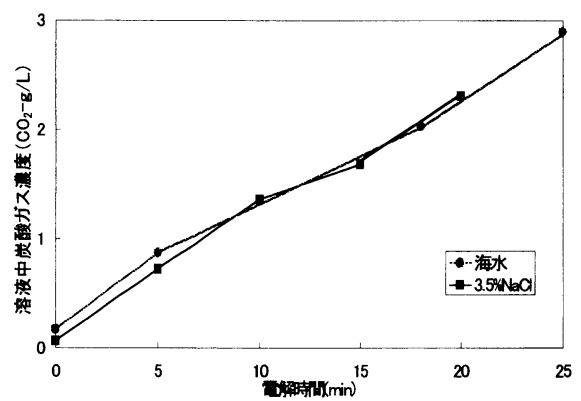

図9 海水及び3.5\% NaCl溶液の電解時間と 炭酸ガスの溶解量の関係 (5A)

水と $3.5 \% \mathrm{NaCl}$ 溶液では差異は認められなかった。 また 10 分間の電解で, 約 10 倍の炭酸ガスが溶解す ることがいえた。

刚 10 に $3.5 \% \mathrm{NaCl}$ 溶液で5A通電のもとで，隔 膜の孔径 $(\phi 1 \mu \mathrm{m}, \phi 0.5 \mu \mathrm{m})$ による違いが $\mathrm{CO}_{2}$ 溶解 量への影響を調べた。忷より孔径 $0.5 \mu \mathrm{m}$ の隔膜を 使用した場合がわずかに炭酸ガス溶解量が高く現 れたが，大差はなかった。

〔隔膜〕PTEF 孔径 : $1 \mu \mathrm{m}$, 多孔度 : $80 \%$, 厚さ : $120 \mu \mathrm{m}$ PTEF 孔径 : $0.5 \mu \mathrm{m}$, 多孔度 : $79 \%$, 厚さ : $35 \mu \mathrm{m}$ 〔通気ガス〕 $5 \%$ 炭酸ガス, 流量 : $11 / \mathrm{min}$

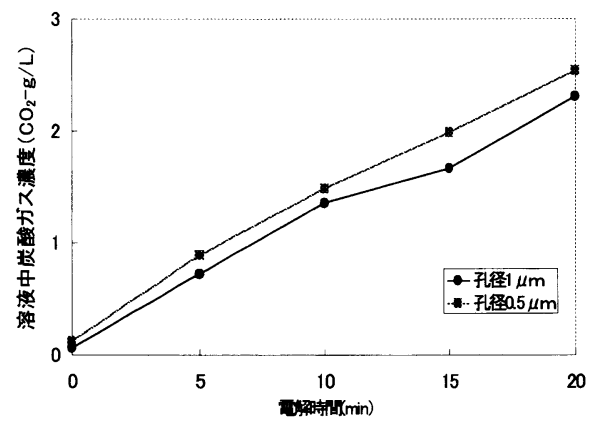

図10 炭酸ガス溶解量に及ぼす孔径の影響 (3.5\% NaCl溶液,5A電解)

\section{3 炭酸ガス除去率 図11には，5Aで10分} 間通電のもとで, 海水カソード液中の炭酸ガス濃 度変化 (溶解量) と気体の単位時間あたり炭酸ガス 除去率 $(\%)$ を通気時間に対して示した。炭酸ガス 初期濃度は99Vol.\%である。通気時間が約3分まで は液中の $\mathrm{CO}_{2}$ 濃度が急に増加しているが，4分以降

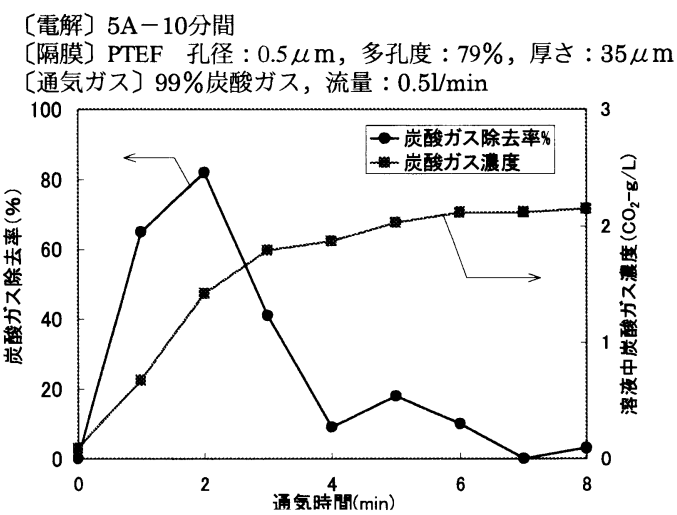

図11 海水カソード液中の炭酸ガス濃度変化と 炭酸ガス除去率

はほぼフラットである。約 2 分で $\mathrm{CO}_{2}$ ガスの除去率 は約80\%に達することがわかった。

さらに, 電気分解後の種々の $\mathrm{pH}$ 值を有するイオ ン水に $\mathrm{CO}_{2}$ ガスが溶解する状態を図 12 に示した ${ }^{3)}$. 海水量 $2 \mathrm{dm}^{3}$ 中に初期濃度 $4.5 \%$ の $\mathrm{CO}_{2}$ を， $4 \mathrm{~L} / \mathrm{min}$ で注入した後の電解槽出口の $\mathrm{CO}_{2}$ 量を○でプロッ トした。困より，強アルカリ $(\mathrm{pH} \fallingdotseq 10)$ 状態では $\mathrm{CO}_{2}$ 溶解が著しく約 $56 \%$ 削減された。

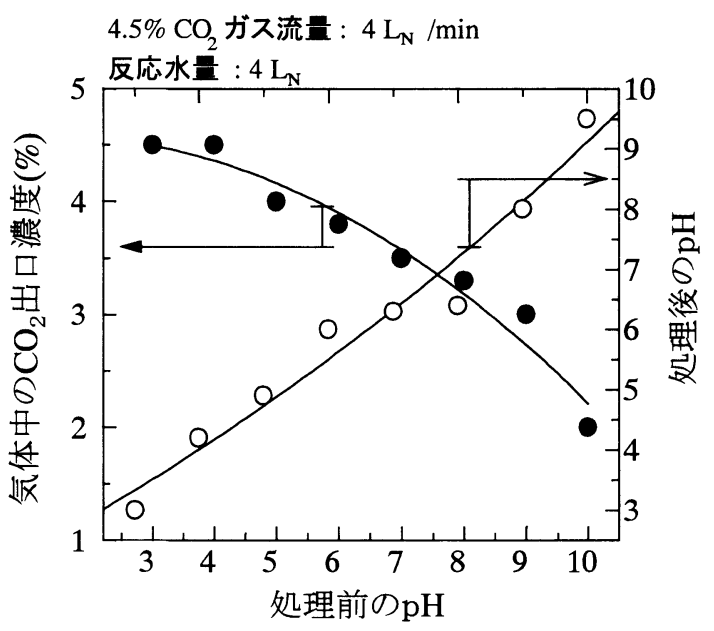

図12 $\mathrm{pH}$ 值に対する $\mathrm{CO}_{2}$ 溶解による削減量

電解水を炭酸ガス処理後に海水に放流した場合 を仮定し，一度処理した炭酸ガスが大気放出され る状態を調べるために, 処理後の溶液を海水に入 れたときの溶液中の炭酸ガスの濃度変化を放置時 間に対して示したのが図13である。初期濃度が 


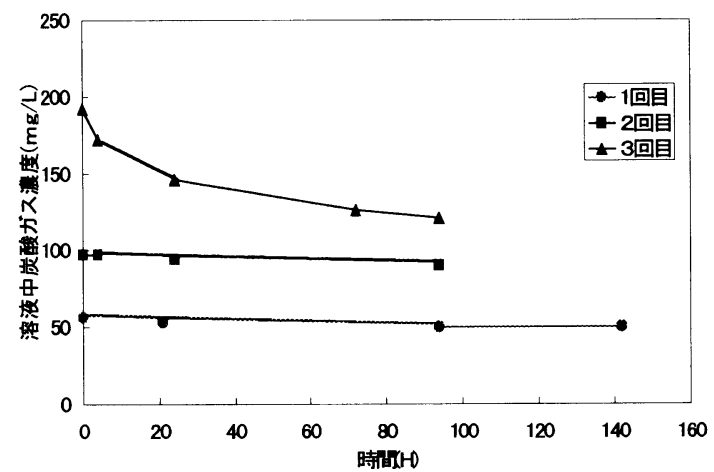

図13 海水(炭酸ガス処理後の溶液を含む) 中の 炭酸ガスの濃度変化

$200 \mathrm{mg} / \mathrm{L}$ の場合は時間の経過とともに炭酸ガスが 大気に放出されたため海水中の炭酸ガス濃度は下 がっているが，初期濃度が $100 \mathrm{mg} / \mathrm{L}, 50 \mathrm{mg} / \mathrm{L} の$ 場合に打いては, 海水中の炭酸ガス濃度はほぼ一 定であり．炭酸ガスの大気への放出が少ないこと がわかった。

\section{5. まとめ}

海水の電気分解法のための電解槽 (卓上型) の性 能評価を行った後 $\mathrm{CO}_{2}$ の溶液反応による削減法を 基礎的立場から行った。

つぎのようなことがいえた。
（1）海水利用によるアルカリ $(\mathrm{NaOH})$ 生成のため の電流効率は電解時間 10 分以降で約 $90 \%$ 以上

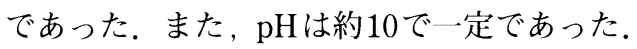

（2）カソード液の炭酸ガス吸収能は，5Aで10分間 電解した場合, 未処理の海水に比べて 10 倍以 上の効果があった。

（3）炭酸ガス除去率において，5Aの通電で，2分 後に最も高い $80 \%$ に達することがわかった.

打わりに，本研究の遂行にあたり，芝浦工業大 学大学院客員教授 平田 賢先生のご助言と, 運 輸施設設備事業団のご支援を得ました。深心より 謝意をもうしあげます。

\section{文献}

1）平田ら, 他 29 名, 平成 12 年度船舶排出大気污染物質削 減手法検討調査報告書 (環境省委託事業), (社) 日本又 リンエンジニアリング学会, (平成 13 年 3 月)，P． 35.

2）綾 威男, $\mathrm{CO} 2$ を深海底の篗地に溜めよう, シップ・ア ンド・オーシャン財団Ship\&Ocean Newsletter, No.34 (Jan.5,2002), P.8 9.

3) Sukheon An,Osami Nisida, et.al.6,Basic Research for Using Electrolyzed Seawater in Air Pollution Controlsystem Development of Large Marine Diesel Engine, Proceedings Busan Engine International Symposium 2001 Busan,Korea, (December 12 14,2001), PP.267 271 . 